Research Article

\title{
Anti-hyperalgesic effect of paracetamol in rat model of thermal hyperalgesia: implications for the treatment of neuropathic pain
}

\author{
Mangesh A. Bankar ${ }^{1}$, Sujata S. Dudhgaonkar ${ }^{2}$
}

\begin{abstract}
${ }^{1}$ Department of Pharmacology, Government Medical College, Nagpur, India

${ }^{2}$ Department of Pharmacology, Indira Gandhi Government Medical College, Nagpur, India

Received: 12 February 2013

Revised: 8 April 2013

Accepted: 9 April 2013

*Correspondence to:

Dr. Mangesh A. Bankar,

Email:

drmangesh_bankar@yahoo.co.in

(C) 2013 Bankar MA et al. This is an open-access article distributed under the terms of the Creative Commons Attribution License, which permits unrestricted use, distribution, and reproduction in any medium, provided the original work is properly cited.
\end{abstract}

\begin{abstract}
Background: Neuropathic pain conditions are prevalent in general population and difficult to treat. Most currently available therapies do not provide adequate benefit in all treated patients. Though Paracetamol is available for more than 100 years and have huge safety data, it is still not included in any treatment guidelines for neuropathic pain, as very few studies have evaluated its effects in neuropathic pain conditions. The aim of this study was to evaluate antihyperalgesic activity of paracetamol and to compare it with antihyperalgesic effect of amitriptyline and gabapentin in rat model of thermal hyperalgesia.

Methods: Male albino wistar rats weighing 200-250 $\mathrm{g}$ of body weight and 4-6 months old were used. After anaesthetizing rats with $2 \%$ halothane, mild thermal injury was induced using hot plate analgesiometer. Drugs were administered intraperitoneally 30 minutes after thermal injury. Paw withdrawal latencies were measured at 30, 60, 90 and 120 minutes after drug administration. Statistical analysis done using GraphPad Prism version 5.01 and one way ANOVA followed by post hoc Dunnett's test or Tukey's test were used. Results: Paracetamol showed both dose as well as time dependent antihyperalgesic activity. Gabapentin demonstrated significantly more antihyperalgesic activity compared to amitriptyline $(p<0.05)$ and paracetamol $(p<0.01)$.

Conclusions: Paracetamol showed antihyperalgesic activity however, it was less as compared to drugs like gabapentin and amitriptyline. Considering the excellent safety profile of paracetamol, it might be useful adjuvant drug for treatment of neuropathic pain conditions.
\end{abstract}

Keywords: Acetaminophen, Hyperalgesia, Neuropathic pain, Gabapentin, Paw withdrawal latency

\section{INTRODUCTION}

Neuropathic pain (NP) conditions develop due to disorders resulting from damage or disease of the central or peripheral nervous system or both. ${ }^{1}$ Due to different causative factors, NP conditions may be prevalent in general population. Though exact prevalence is difficult to estimate, previous studies have reported overall prevalence of NP in general population to be around $6-7 \% .^{2} \mathrm{NP}$ conditions put significant economic burden on health care services and patients. It is estimated that per patient annual cost for treatment of peripheral diabetic neuropathy (PDN) and post herpetic neuralgia (PHN) to be around US \$1000 and $£ 1600$ respectively. Treatment of NP is a challenging task for a physician as not all of the treated patients get satisfactory treatment response. Sometimes it can cause extreme discomfort and adversely affecting quality of life of the patient. $^{3,4}$

Two prominent symptoms of NP are allodynia i.e. even non noxious stimulus can elicit severe pain response and hyperalgesia i.e. increased pain response to noxious stimulus. Thermal hyperalgesia include cold hyperalgesia which is seen in $21 \%$ of patient suffering from postherpetic neuralgia whereas heat hyperalgesia is seen in $25 \%$ patient following nerve damage. ${ }^{5}$ As per EFNS guidelines for treatment of NP, oxcarbamazepine and carbamazepine are the first line agents for trigeminal neuralgia (TN). Gabapentin (GBP), pregabalin and tricyclic antidepressants (TCA) are first line agents for various painful peripheral as well as central neuropathic 
conditions. Duloxetine and venlafaxine are other recommended first line drugs for PDN. Opioids and tramadol are recommended as second line agents for various neuropathic conditions including central as well as peripheral NP conditions except TN in which surgery is the recommended second line treatment option. ${ }^{6}$

Recent Cochrane review has suggested that GBP can provide pain relief in NP conditions like PHN, PDN and mixed NP conditions. However, it effectively controls pain in less than half $(43 \%)$ of treated patients only at doses above $1200 \mathrm{mg} /$ day whereas rest of the patients will not get satisfactory pain relief with GBP alone. Though incidence of serious adverse drug reactions (ADRs) is less with GBP, patient's compliance is generally poor due to various common ADRs including somnolence, dizziness, peripheral oedema and gait abnormalities. ${ }^{7}$

Various antidepressants including amitriptyline (AMT) and venlafaxine are used for the treatment of NP but only one third of the treated patients get satisfactory pain relief. Like GBP, patient compliance is extremely poor and approximately one fifth $(20 \%)$ of the patients receiving these medications will stop treatment due to intolerable ADRs such as drowsiness, dry mouth, blurred vision, constipation and urinary retention. ${ }^{8}$

Though paracetamol (PCM) is a widely used analgesic and has been in use for more than 100 years, its exact mechanism of action is still not clearly understood. ${ }^{9}$ However, studies have demonstrated beneficial effect of PCM in NP models. Dani et al. studied local antinociceptive effect of PCM in rat model of NP where they observed dose dependent reduction in nociceptive scores by PCM. ${ }^{10}$ Similarly Lynch et al. observed efficacy of PCM in suppressing mechanical allodynia in vincristine induced NP model in rats. ${ }^{11}$

Many physicians still believe that PCM has no role in the treatment of NP. Moreover none of the currently available guidelines for the treatment of NP recommend use of PCM for treatment of NP conditions because scarce amount of data is available regarding the efficacy of PCM in neuropathic pain. Previous reports have shown that experimental model of hyperalgesia can be a useful indicator of clinical efficacy of analgesic drugs against NP. ${ }^{12}$ Therefore this study was undertaken to demonstrate anti-hyperalgesic (AHA) effect of PCM in a simple model of thermal hyperalgesia in rats.

Following were the aims and objectives of this study.

1) To evaluate the AHA activity of PCM using thermal model of hyperalgesia in rats.

2) To compare the AHA effect of PCM with AMT and GBP in above model of thermal hyperalgesia.

\section{METHODS}

Animals used: After the approval of Institutional animal ethics committee, male albino wistar rats weighing 200$250 \mathrm{~g}$ of body weight and 4-6 months old, purchased from National Center for Laboratory Animal Sciences (NCLAS), National Institute of Nutrition, Jamai Osmania, Hyderabad-500007. Rats were individually housed and maintained on a 12 -h light/ 12 -hr dark cycle at $22^{\circ} \mathrm{C}$. Food and water were provided ad libitum. Experiments were performed between 9.00 A.M. and 15.00 P.M. in a noiseless and illuminated room. Experiments were conducted in accordance with international Association for study of pain (IASP) guidelines. Each behavioural testing session was preceded by 20 minute (min) acclimatization to the observation chamber.

Drugs and Chemicals: In the present study we used GBP (Cap. Neurontin; Manufacturer- Parke Davis), AMT (Tab. Amitone; Manufacturer- Intas) and PCM (Inj. Febrenil; Manufacturer- Sigma Pharma). The drugs were dissolved in their respective solvents i.e. paracetamol and amitriptyline in saline whereas gabapentin in tween 80 . All drugs were injected intraperitoneally (IP). All aseptic precautions were taken while administering the drugs to the animals. Halothane 2\% was purchased from Merck (Mumbai).

Procedure: In the present study, to induce clear thermal hyperalgesia, a mild thermal injury was induced to the plantar surface of the right hind paw of rat. The rat was first anaesthetized in an induction box with halothane $(2 \%)$. Any spontaneous movements or movements in response to toe pinch were carefully observed. After absence of any such movements, plantar surface of the right hind paw of the rat was kept for duration of 45 seconds on the surface of eddy's hot plate analgesiometer (Techno). The temperature of the hot plate analgesiometer was maintained between $51.5^{\circ}$ to $53.5^{\circ} \mathrm{C}$. During this procedure, mild pressure was applied on the hind paw in order to ensure uniform exposure of the plantar surface of the paw. After the removal of paw from the surface, a significant thermal hyperalgesia was observed by $30 \mathrm{~min}$ and this was sustained for approximately $3 \mathrm{hrs}$. This procedure did not produce blistering of paw during the subsequent 24-h interval. To measure the thermal escape latency, the rat was placed on hot-plate surface, which was maintained between $51.5^{\circ}$ to $53.5^{\circ} \mathrm{C}$. The rats were again placed on the hot plate analgesiometer and the time until the brisk hind paw withdrawal response was recorded by a stop watch. In order to prevent any injury to animal, a cut off time of 20 seconds was used. Drugs were given by intraperitoneal (IP) injection $30 \mathrm{~min}$ after the thermal injury whereas experiments to test efficacy of drugs were started after 30 min of drug administration. ${ }^{13}$ Animals were divided into 11 groups, each of 6 animals. Control group received saline $(0.9 \%)$ or tween 80 (3\% aqueous). With remaining groups, three sets of experiments were performed. 
The first set of experiment involved measurement of dose-related and time-related paw withdrawal latency (PWL) of IP PCM. Three groups of rats received three different doses of PCM, i.e. 25, 50 and $100 \mathrm{mg} / \mathrm{kg}$. Thermal injury was induced $30 \mathrm{~min}$ prior to drug administration. Paw withdrawal latencies (PWLs) were measured at 30, 60, 90 and $120 \mathrm{~min}$ after the drug administration. Control group received IP saline. The second set of experiment involved measurement of dose-related and time related PWLs of IP AMT. Three groups of rats received three different doses of AMT i.e. $1.5,3$ and $5 \mathrm{mg} / \mathrm{kg}$. Thermal injury was induced $30 \mathrm{~min}$ prior to drug administration. PWLs were measured at 30, 60, 90 and $120 \mathrm{~min}$ after the drug administration. Control group received IP saline. The third set of experiment involved measurement of dose-related and time-related PWL of IP GBP. Three groups of rats received three different doses of GBP i.e. 10, 30 and 50 $\mathrm{mg} / \mathrm{kg}$. Thermal injury was induced $30 \mathrm{~min}$ prior to drug administration. The PWLs were measured at 30, 60, 90 and $120 \mathrm{~min}$ after the drug administration. Control group received IP tween $80(3 \%)$.

Statistical analysis was done by using graphpad prism version 5.01 (GraphPad Software, Inc., CA 92037, USA). Data were expressed as mean \pm S.E.M. differences between vehicle, control and treatment groups were tested using one-way ANOVA followed by multiple comparisons by the post hoc Dunnett's test (for comparison with control group at respective time level and with reading at $30 \mathrm{~min}$ at respective dose level) and Tukey's test (for within group and intergroup comparison). $p$ values less than 0.05 were considered statistically significant.

\section{RESULTS}

Using thermal hyperalgesia model in rats, PWLs were measured as an indicator of AHA activity of PCM, AMT and GBP and were compared in between.

As per results presented in Table 1, all three doses of PCM $(25,50,100 \mathrm{mg} / \mathrm{kg})$ produced AHA effect (increased PWL) when compared to control at respective time level except PCM $25 \mathrm{mg} / \mathrm{kg}$ at 30 and $60 \mathrm{~min}$. Also when values (PWLs) observed at 60, 90, $120 \mathrm{~min}$ are compared with $30 \mathrm{~min}$ reading, all the three doses of PCM at 90 and 120 min showed statistically significant increase in PWLs.

As per results presented in Table 1, within group comparison of effect on PWLs by different doses of PCM at different time levels showed that PCM $100 \mathrm{mg} / \mathrm{kg}$ at 90 or $120 \mathrm{~min}$ produced significantly increase in PWL as compared to PCM $25 \mathrm{mg} / \mathrm{kg}$ and PCM $50 \mathrm{mg} / \mathrm{kg}$ at 30 min. Also low dose PCM $(25 \mathrm{mg} / \mathrm{kg})$ showed significant increase in the PWLs as compared to PCM $50 \mathrm{mg} / \mathrm{kg}$ at 30 min. Similarly PCM 50mg/kg at 90 and 120 min showed significant increase in the PWLs as compared to high dose $(100 \mathrm{mg} / \mathrm{kg}) \mathrm{PCM}$ at $30 \mathrm{~min}$.

Table 1: Comparison of effects of different doses of PCM on PWLs in rats.

\begin{tabular}{|c|c|c|c|c|c|}
\hline \multirow{2}{*}{ Drug } & \multirow{2}{*}{$\begin{array}{l}\text { Dose } \\
\text { mg/kg }\end{array}$} & \multicolumn{4}{|c|}{ Time after drug administration } \\
\hline & & 30min & $60 \mathrm{~min}$ & $90 \mathrm{~min}$ & $120 \mathrm{~min}$ \\
\hline Control & & $7.308 \pm 0.4884$ & $7.91 \pm 0.3301$ & $7.688 \pm 0.549$ & $7.395 \pm 0.3532$ \\
\hline PCM & 25 & $8.483 \pm 0.3351$ & $9.461 \pm 0.4399$ & $10.595 \pm 0.6183 * * * \#$ & $11.045 \pm 0.4163 * * * \# \#, \mathrm{f}$ \\
\hline PCM & 50 & $8.98 \pm 0.2913 *$ & $10.485 \pm 0.529 * * \#$ & $12.075 \pm 0.1235 * * * \# \# \# \mathrm{a}, \mathrm{b}, \mathrm{k}$ & $12.44 \pm 0.4449 * * * \# \# \# \mathrm{a}, \mathrm{s}, \mathrm{m}, \mathrm{q}$ \\
\hline PCM & 100 & $9.473 \pm 0.4504 * *$ & $10.271 \pm 0.4484 * *$ & $11.10 \pm 0.4058 * * * \#, \mathrm{c}, \mathrm{g}$ & $12.458 \pm 0.4410 * * * \# \# \# d, e, h$ \\
\hline
\end{tabular}

PWLs are expressed as mean \pm S.E.M; $\mathrm{n}=6 ; *=p<0.05, * *=p<0.01$ and $* * *=p<0.001$ when compared to control at respective time level; \# = $p<0.05$; \#\# = p<0.01 and \#\#\#=p<0.001 when compared to 30 min reading at respective dose level. a: $p<0.001$ vs. PCM $25 \mathrm{mg} / \mathrm{kg}$ at $30 \mathrm{~min}$; b: $p<0.01 \mathrm{vs}$. PCM $25 \mathrm{mg} / \mathrm{kg}$ at $60 \mathrm{~min}$; s: $p<0.001 \mathrm{vs}$. PCM $25 \mathrm{mg} / \mathrm{kg}$ at $60 \mathrm{~min}$; c: $p<0.01$ vs. PCM $25 \mathrm{mg} / \mathrm{kg}$ at $30 \mathrm{~min}$; d: $p<0.001 \mathrm{vs.} \mathrm{PCM} 25 \mathrm{mg} / \mathrm{kg}$ at $30 \mathrm{~min}$; e: $p<0.01 \mathrm{vs}$. PCM $25 \mathrm{mg} / \mathrm{kg}$ at $60 \mathrm{~min}$; f: $p<0.05$ vs. PCM $50 \mathrm{mg} / \mathrm{kg}$ at $30 \mathrm{~min} ; \mathrm{g}: p<0.05$ vs. PCM $50 \mathrm{mg} / \mathrm{kg}$ at $30 \mathrm{~min} ; \mathrm{h}: p<0.001 \mathrm{vs}$. PCM $50 \mathrm{mg} / \mathrm{kg}$ at $30 \mathrm{~min}$; k: $p<0.01$ vs. PCM $100 \mathrm{mg} / \mathrm{kg}$ at $30 \mathrm{~min} ; \mathrm{m}: p<0.001$ vs. PCM $100 \mathrm{mg} / \mathrm{kg}$ at $30 \mathrm{~min} ; \mathrm{q}: p<0.05 \mathrm{vs}$. PCM 100 $\mathrm{mg} / \mathrm{kg}$ at $60 \mathrm{~min}$. (One way ANOVA followed by Tukey's test). 
Table 2: Effect of AMT (1.5, 3 and $5 \mathrm{mg} / \mathrm{kg})$ on PWLs in rats at 30, 60, 90 and $120 \mathrm{~min}$ post drug administration.

\begin{tabular}{|c|c|c|c|c|c|}
\hline \multirow{2}{*}{ Drug } & \multirow{2}{*}{$\begin{array}{l}\text { Dose in } \\
\mathrm{mg} / \mathrm{kg}\end{array}$} & \multicolumn{4}{|c|}{ Time after drug administration } \\
\hline & & 30min & $60 \mathrm{~min}$ & $90 \mathrm{~min}$ & $120 \mathrm{~min}$ \\
\hline Control & & $7.308 \pm 0.4884$ & $7.91 \pm 0.3301$ & $7.688 \pm 0.549$ & $7.395 \pm 0.3532$ \\
\hline $\mathrm{AMT}$ & 1.5 & $9.481 \pm 0.5672 *$ & $11.216 \pm 0.2886 * * * \#$ & $11.4 \pm 0.6096 * * \#$ & $12.525 \pm 0.3922 * * * \# \# \#$ \\
\hline AMT & 3 & $9.876 \pm 0.5055^{* *}$ & $11.831 \pm 0.4760 * * * \#$ & $12.355 \pm 0.5262 * * * \#$ & $12.5 \pm 0.622 * * * \# \#$ \\
\hline AMT & 5 & $9.67 \pm 0.56^{*}$ & $12.11 \pm 0.4135 * * * \#$ & $12.681 \pm 0.9598 * * * \# \#$ & $11.39 \pm 0.4773 * * *$ \\
\hline
\end{tabular}

PWLs are expressed as mean \pm S.E.M; $\mathrm{n}=6 ; *=p<0.05, * *=p<0.01$ and $* * *=p<0.001$ when compared to control at respective time level; \# = $p<0.05$; \#\# = p<0.01 and \#\#\#=p<0.001 when compared to 30 min reading at respective dose level. (One way ANOVA followed by Dunnett's test)

Table 3: Effect of GBP (10, 30 and $50 \mathrm{mg} / \mathrm{kg})$ on PWLs in rats at 30, 60, 90 and 120 min post drug administration.

\begin{tabular}{|c|c|c|c|c|c|}
\hline \multirow{2}{*}{ Drug } & \multirow{2}{*}{$\begin{array}{l}\text { Dose in } \\
\mathrm{mg} / \mathrm{kg}\end{array}$} & \multicolumn{4}{|c|}{ Time after drug administration } \\
\hline & & 30min & $60 \mathrm{~min}$ & $90 \mathrm{~min}$ & $120 \mathrm{~min}$ \\
\hline Control & & $9.245 \pm 0.2967$ & $9.69 \pm 0.2953$ & $9.631 \pm 0.1896$ & $9.791 \pm 0.1476$ \\
\hline GABA & 10 & $10.115 \pm 0.3402$ & $11.363 \pm 0.3112 *$ & $14.295 \pm 0.331 * * * \# \# \#$ & $13.711 \pm 0.7513 * * * \# \# \#$ \\
\hline GABA & 30 & $9.46 \pm 0.4176$ & $11.665 \pm 0.3824 * * \# \#$ & $13.453 \pm 0.4689 * * * \# \# \#$ & $13.76 \pm 0.3476 * * * \# \# \#$ \\
\hline GABA & 50 & $10.17 \pm 0.492$ & $12.148 \pm 0.4467 * * * \#$ & $13.535 \pm 0.6021 * * * \# \# \#$ & $14.4 \pm 0.2413 * * * \# \# \#$ \\
\hline
\end{tabular}

PWLs are expressed as mean \pm S.E.M; $\mathrm{n}=6 ; *=p<0.05, * *=p<0.01$ and $* * *=p<0.001$ when compared to control at respective time level; \# = $p<0.05$; \#\# = $p<0.01$ and \#\#\#= $p<0.001$ when compared to 30 min reading at respective dose level. (One way ANOVA followed by Dunnett's test).

As per results presented in Table 2, systemic (IP) administration of AMT showed significantly increased PWL sand all three doses of AMT (1.5, 3 and $5 \mathrm{mg} / \mathrm{kg}$ ) showed pronounced AHA activity as compared to control at respective time level. Similarly when values (PWLs) observed at $60,90,120 \mathrm{~min}$ were compared with $30 \mathrm{~min}$ reading, all the three doses showed statistically significant increase in PWLs.

As per results presented in Table 3, GBP showed significantly increased PWLs by all three doses when compared to control group at their respective time level except that PWLs of all three doses observed at $30 \mathrm{~min}$ were comparable with PWLs of control group. Similarly when values (PWLs) observed at 60, 90, 120 min were compared with $30 \mathrm{~min}$ reading, all the three doses of GBP showed statistically significant increase in PWLs at 60, 90 and 120 min compared to reading obtained at 30 min.

Comparison of AHA effect of PCM $(25,50,100 \mathrm{mg} / \mathrm{kg})$ with AMT $(1.5,3,5 \mathrm{mg} / \mathrm{kg})$ and $\operatorname{GBP}(10,30,50 \mathrm{mg} / \mathrm{kg})$ respective time level is presented in Table 4. Effect on PWLs of all three drugs was not significantly different at $30 \mathrm{~min}$ level. However at $60 \mathrm{~min}$ level, both AMT and GBP showed significant AHA effect (increased PWLs) as compared to PCM. Also all three doses of GBP at 120 min level showed significantly increased AHA activity as compared to PCM as well as AMT.

\section{DISCUSSION}

The current study was undertaken to demonstrate AHA activity of PCM in rat model of thermal hyperalgesia and to compare with AHA activity of the AMT and GBP, which are currently available first line agent for various NP conditions in order to judge the potential efficacy of PCM for the treatment of NP.

The current study showed that systemic (IP) administration of PCM $(25,50$ and $100 \mathrm{mg} / \mathrm{kg})$, induced AHA effect using heat induced hyperalgesia model in rats and this effect was both dose as well time dependent. The AHA effect started as early as $30 \mathrm{~min}$ and complete 
reversal of hyperalgesia (increased PWL) was observed at 120 min post drug administration except with PCM $25 \mathrm{mg} / \mathrm{kg}$ group where AHA effect started at $90 \mathrm{~min}$ post drug administration. When AHA effect of PCM was compared with AMT and GBP at different time intervals from $30 \mathrm{~min}$. to $120 \mathrm{~min}$, the results showed that GBP was significantly more effective than AMT from 90 min to 120 min post-drug use in rats, whereas both GBP and AMT were having significantly more AHA effect than PCM.

Table 4: Comparison of antihyperalgesic effect of PCM (25, 50, $100 \mathrm{mg} / \mathrm{kg})$, AMT (1.5, 3, $5 \mathrm{mg} / \mathrm{kg}) \mathrm{and}$ GBP (10, $30,50 \mathrm{mg} / \mathrm{kg}$ ) at respective time level.

\begin{tabular}{|c|c|c|c|c|c|c|c|c|c|}
\hline \multirow{2}{*}{ 를 } & \multicolumn{9}{|c|}{ Drugs and dose in mg/kg } \\
\hline & PCM 25 & PCM 50 & PCM 100 & AMT 1.5 & AMT 3 & AMT 5 & GBP 10 & GBP 30 & GBP 50 \\
\hline $\begin{array}{l}\text { 岁 } \\
\text { E. } \\
\text { E. }\end{array}$ & $\begin{array}{l}8.48 \pm \\
0.36\end{array}$ & $\begin{array}{l}8.98 \pm \\
0.29\end{array}$ & $\begin{array}{l}9.47 \pm \\
0.45\end{array}$ & $\begin{array}{l}9.48 \pm \\
0.57\end{array}$ & $\begin{array}{l}9.88 \pm \\
0.51\end{array}$ & $\begin{array}{l}9.67 \pm \\
0.56\end{array}$ & $\begin{array}{l}10.11 \pm \\
0.34\end{array}$ & $\begin{array}{l}9.46 \pm \\
0.42\end{array}$ & $\begin{array}{l}10.17 \pm \\
0.49\end{array}$ \\
\hline $\begin{array}{l}\text { ఠે } \\
\text { छ. }\end{array}$ & $\begin{array}{l}9.46 \pm \\
0.44\end{array}$ & $\begin{array}{l}10.49 \pm \\
0.53\end{array}$ & $\begin{array}{l}10.27 \pm \\
0.45\end{array}$ & $\begin{array}{l}11.21 \pm \\
0.29\end{array}$ & $\begin{array}{l}11.83 \pm \\
0.48^{\mathrm{a}}\end{array}$ & $\begin{array}{l}12.11 \pm \\
0.41^{\mathrm{b}}\end{array}$ & $\begin{array}{l}11.36 \pm \\
0.31\end{array}$ & $\begin{array}{l}11.67 \pm \\
0.38^{c}\end{array}$ & $\begin{array}{l}12.15 \pm \\
0.45^{d}\end{array}$ \\
\hline 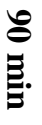 & $\begin{array}{l}10.60 \pm \\
0.62\end{array}$ & $\begin{array}{l}12.08 \pm \\
0.12\end{array}$ & $\begin{array}{l}11.1 \pm \\
0.41\end{array}$ & $\begin{array}{l}11.4 \pm \\
0.61\end{array}$ & $\begin{array}{l}12.34 \pm \\
0.53\end{array}$ & $\begin{array}{l}12.68 \pm \\
0.96\end{array}$ & $\begin{array}{l}14.30 \pm \\
0.33^{\mathbf{e , f , g}}\end{array}$ & $\begin{array}{l}13.45 \pm \\
0.47^{\text {h }}\end{array}$ & $\begin{array}{l}13.54 \pm \\
0.60^{k}\end{array}$ \\
\hline$\vec{N}$ & $\begin{array}{l}11.05 \pm \\
0.42\end{array}$ & $\begin{array}{l}12.44 \pm \\
0.44\end{array}$ & $\begin{array}{l}12.46 \pm \\
0.44\end{array}$ & $\begin{array}{l}12.53 \pm \\
0.39\end{array}$ & $\begin{array}{l}12.5 \pm \\
0.62\end{array}$ & $\begin{array}{l}11.39 \pm \\
0.48\end{array}$ & $\begin{array}{l}13.71 \pm \\
0.75^{\text {n,q }}\end{array}$ & $\begin{array}{l}13.76 \pm \\
0.35^{r, s}\end{array}$ & $\begin{array}{l}14.4 \pm \\
0.24^{t, u}\end{array}$ \\
\hline
\end{tabular}

PWLs are expressed as mean \pm S.E.M; Time in minutes; $\mathrm{n}=6$; $\mathrm{a}: p<0.01$, b: $p<0.01, \mathrm{c}: p<0.05$ and d: $p<0.01$ vs. PCM 25 $\mathrm{mg} / \mathrm{kg}$ at $60 \mathrm{~min}$; e: $p<0.001 \mathrm{vs}$. PCM $25 \mathrm{mg} / \mathrm{kg}$, f: $p<0.01 \mathrm{vs.} \mathrm{PCM} 100 \mathrm{mg} / \mathrm{kg}$, g: $p<0.05 \mathrm{vs.} \mathrm{AMT} 1.5 \mathrm{mg} / \mathrm{kg}, \mathrm{h}: p<0.05$ vs. PCM $25 \mathrm{mg} / \mathrm{kg}$, k: $p<0.05$ vs. PCM $25 \mathrm{mg} / \mathrm{kg}$ at $90 \mathrm{~min} ; \mathrm{n}: p<0.01 \mathrm{vs.} \mathrm{PCM} 25 \mathrm{mg} / \mathrm{kg}$, q: $p<0.05 \mathrm{vs}$. AMT $5 \mathrm{mg} / \mathrm{kg}$, r: $p<0.01$ vs. PCM $25 \mathrm{mg} / \mathrm{kg}$, s: $p<0.05$ vs. AMT $5 \mathrm{mg} / \mathrm{kg}$, t: $p<0.001 \mathrm{vs.} \mathrm{PCM} 25 \mathrm{mg} / \mathrm{kg}, \mathrm{u}: p<0.01 \mathrm{vs}$. AMT $5 \mathrm{mg} / \mathrm{kg}$ at $120 \mathrm{~min}$; (one way ANOVA followed by Tukey's test).

The finding that GBP is superior to AMT is consistent with an open label 12 week duration pilot trial conducted by Dallacchio et al. for comparing efficacy and tolerability of GBP with AMT in 25 type II diabetic patients suffering from pain due to diabetic polyneuropathy. They observed that GBP was not only more superior in reducing pain score as well as paresthesia score but also produced less side effects as compared to AMT. ${ }^{14}$

GBP and AMT are recommended first line options for management of various neuropathic pain conditions. GBP exerts its action by binding to $\alpha_{2} \delta$ subunit of calcium channels and decreasing the release of several neurotransmitters such as glutamate, norepinephrine and Substance $\mathrm{P}$ suppressing the hyper-excitability of peripheral neurons causing pain relief. ${ }^{15,}{ }^{16}$ GBP exert AHA action probably by acting in brain stem thereby causing descending inhibition and anti-allodynic action probably by altering microglial functions. ${ }^{17}$

Beneficial effects of AMT in NP are independent of antidepressant action as indicated by requirement of low dose (25-100 mg daily) for analgesic action than antidepressant action. ADRs of AMT are common and around one third patient suffer from mild adverse effects while $8 \%$ of the patient stop taking drug due to severe adverse effects. ${ }^{18}$

AMT inhibit reuptake of noradrenaline and serotonin increasing the level of these neurotransmitters in synaptic cleft. Thus AMT potentiates the activity of noradrenergic and serotonergic transmission systems which originate in the brain stem and descend to the spinal cord which in turn enhance the dorsal root inhibition, decreasing the input of afferent painful stimuli to CNS and reducing the peripheral sensitization. Other possible analgesic mechanisms suggested for AMT include increase in the release of endogenous opioids, blockade of N-methyl-Daspartate (NMDA) receptors, blockade of $\mathrm{Na}^{+}$and $\mathrm{N}$ type $\mathrm{Ca}^{+}$channels and opening of $\mathrm{K}^{+}$channels. ${ }^{19,20}$

Several mechanisms of anti-nociceptive activity of PCM have been proposed by different researchers but the exact mechanism of action still remains to be elucidated. First well known and widely accepted mechanism includes inhibition of several isoforms of cyclooxygenase (COX) enzyme. Studies conducted on COX-1 knockout mice 
suggest that PCM might produce anti-nociception through inhibition of COX1 enzyme. Also it has been proposed that PCM might favour central COX-1 compared to peripheral COX-1 enzyme. However as antipyretic activity was not affected in COX-1 knockout mice and reason why PCM have propensity towards central COX-1 than peripheral COX1 is not known, it has been suggest that PCM might act through other actions also. ${ }^{9,21}$ Other researchers have suggested the role of COX-2 and COX-3 enzyme inhibition as well. However, ADRs of PCM are different than selective COX-2 enzyme inhibitors and pain is neither mediated by COX-3 enzyme nor it is discovered in humans. Indirect inhibition of COX enzyme by PCM has also been proposed where PCM being the phenol, act as powerful reducing agent and oxidize the COX enzyme to its inactive form. ${ }^{22-24}$

Action of PCM through endocannabinoid system has also been proposed. One of the metabolite of PCM is $\mathrm{N}$ Arachidonoyl phenolamine (AM404) which indirectly stimulate endocannabinoid system by blocking cellular reuptake of endogenous cannabinoids such as anandamide as well as act directly by activating TRPV1 (transient receptor potential vanilloid) which is a known CB-1 (cannabinoid-1) receptor agonist. ${ }^{25}$ Another possible mechanism of action suggested for PCM is that by increasing level of serotonin from serotonergic neurons originating from raphe nucleus of brainstem and extending down to spinal cord and establishing connections with afferent neurons carrying pain signals. As discussed earlier stimulation of inhibitory descending serotonergic pathway prevents transmission of pain signals from afferent neurons to higher CNS centres producing analgesia. ${ }^{26} \mathrm{PCM}$ might also exert its antinociceptive action by inhibiting the enzyme nitric oxide synthase which is produced in response to stimulation of NMDA receptors and have role in enhancing neuronal excitability and persistence of pain. ${ }^{27}$

Few researchers have reported negative results about PCM in treatment of neuropathic pain. Curros-Criado et al. concluded that after induction of mononeuropathy using sciatic nerve technique in rats, intrathecal or intravenous administration of PCM showed no significant reduction in neuropathic pain. ${ }^{28}$ Similarly Matsunaga et al. in their study using streptozotocin-induced mechanical hyperalgesia in rats reported that intrathecal administration of PCM did not attenuate hyperalgesia. ${ }^{29}$ These findings are inconsistent with results of present study. Im et al. have discussed various reasons for obtaining such contradictory results in animal studies including type of animal models used, different animals used for the study, age of the animals and route of administration, all can affect results. Im et al. also argued that mere occurrence of positive results in animal studies does not guarantee positive findings in human clinical trials also. For this they cited evidence about AMT and opioids where negative results were initially obtained in many animal studies on NP. Later subsequent animal studies and human clinical trials confirmed efficacy of these drugs in NP syndromes and now these are recommended therapeutic options for management of $\mathrm{NP}^{30}$

Present study showed that efficacy of PCM in reducing hyperalgesia is lower than GBP and AMT. However coadministration of two compounds with different mechanism of action may achieve analgesia at lower dose than required for either compound alone, leading the enhanced pain relief. ${ }^{31}$ Gatti et al. reported in a prospective open label study that fixed dose combination of PCM $325 \mathrm{mg}$ and oxycodone $8 \mathrm{mg}$ thrice daily produced greater improvement in NP symptoms. ${ }^{32}$ Similarly other researchers also reported significant reduction in mean final pain score using tramadol 37.5$300 \mathrm{mg}+\mathrm{PCM} 325-2600 \mathrm{mg}$ combination when compared to placebo. $^{33}$ Very few studies using combination of PCM+GBP have been reported so far. In a study by Hama et al., PCM+GBP combination showed 2.6 fold greater efficacy than GBP alone in rat model of spinal neuropathic injury. ${ }^{34}$ In another short term clinical study preoperative $\mathrm{PCM}+\mathrm{GBP}$ combination was used for reduction of post-operative neural sensitization to achieve early pain relief. Combination showed greater pain relief and also significantly decreased opioid requirement post operatively than GBP alone or placebo. ${ }^{35}$ Dose dependent and time dependent action seen with PCM in the present study is consistent with previous study. Peak plasma concentration after oral administration of PCM is achieved after 33 minutes. Peak concentration in frontal cortex achieved at 15 min after administration whereas in cerebellum it is achieved at $120 \mathrm{~min}$ post drug administration. Hence maximum effect of PCM was seen at $120 \mathrm{~min}^{9}$

In conclusion, results of present study showed that PCM have an AHA activity i.e. it successfully antagonized NP like behaviour in rats using simple thermal model of hyperalgesia. However efficacy of PCM in antagonizing NP like behaviour was less than AMT and GBP. Multimodal analgesia is combining different drugs with different mechanism of actions can be extremely useful and rational method for effective control of severe pain. NP is difficult to treat and not all patients benefit adequately with the currently available drugs. Drug development process for treatment of NP has been continuously going on but it is very time consuming. So in the meantime we can utilize currently available drugs like PCM with extensive safety data in hand as an adjuvant or in fixed dose combinations with the currently marketed drugs for treatment of NP. However, despite extremely favourable side effect profile of PCM, identification of safe and effective drug combinations will require further clinical and experimental research. Although PCM is available for more than a century, its exact mechanism of action is still not understood, so for development of drugs with similar actions, less adverse effects but with greater efficacy, further research is required to find the exact mechanism of action of PCM. 
We used simple thermal hyperalgesia model in the present study which successfully induced NP like behaviour in rats, however use of proper NP animal model would have further substantiated the utility of PCM in treatment of NP. Secondly we did not evaluate efficacy of any PCM combinations like PCM+GBP or PCM+AMT in the present study. It would have yielded further data about efficacy of such combinations for management of NP.

\section{Funding: None}

Conflict of interest: None declared

Ethical approval: The study was approved by the Institutional Animal Ethics Committee

\section{REFERENCES}

1. McCarberg BH, Billington $\mathrm{R}$. Consequences of neuropathic pain: quality of life issues and associated costs. Am J Manag Care 2006;12(9 Suppl):S263-8.

2. Vinik A. The approach to the management of the patient with neuropathic pain. J Clin Endocrinol Metab 2010;95:4802-11.

3. Sarzi-Puttini P, Vellucci R, Zuccaro SM, Cherubino P, Labianca R, Fornasari D. The appropriate treatment of chronic pain. Clin Drug Investig 2012;32 Suppl 1:21-33.

4. Smith BH, Torrance N. Epidemiology of neuropathic pain and its impact on quality of life. Curr Pain Headache Rep 2012;16:191-8.

5. Maier C, Baron R, Tölle TR, Binder A, Birbaumer $\mathrm{N}$, Birklein F, et al. Quantitative Sensory Testing in the German Research Network on Neuropathic Pain (DFNS): somatosensory abnormalities in 1236 patients with different neuropathic pain syndromes. Pain 2010;150:439-50.

6. Attal N, Cruccu G, Baron R, Haanpää M, Hansson $\mathrm{P}$, Jensen TS, Nurmikko T. EFNS guidelines on the pharmacological treatment of neuropathic pain: 2010 revision. Eur J Neurol 2010;17:1113-e88.

7. Moore RA, Wiffen PJ, Derry S, McQuay HJ. Gabapentin for chronic neuropathic pain and fibromyalgia in adults. Cochrane Database Syst Rev 2011;3:CD007938. doi: 10.1002/14651858.CD007938.pub2.

8. Saarto T, Wiffen PJ. Antidepressants for neuropathic pain. Cochrane Database Syst Rev 2007;4:CD005454. doi: 10.1002/ 14651858.CD005454.pub2.

9. Toussaint K, Yang XC, Zielinski MA, Reigle KL, Sacavage SD, Nagar S, Raffa RB. What do we (not) know about how paracetamol (acetaminophen) works? J Clin Pharm Ther 2010;35:617-38.

10. Dani M, Guindon J, Lambert C, Beaulieu P. The local antinociceptive effects of paracetamol in neuropathic pain are mediated by cannabinoid receptors. Eur J Pharmacol 2007;573(1-3):214-5.

11. Lynch JJ 3rd, Wade CL, Zhong CM, Mikusa JP, Honore P. Attenuation of mechanical allodynia by clinically utilized drugs in a rat chemotherapyinduced neuropathic pain model. Pain 2004 J;110(12):56-63.

12. Hargreaves K, Dubner R, Brown F, Flores C, Joris J. A new and sensitive method for measuring thermal nociception in cutaneous hyperalgesia. Pain 1988;32:77-88.

13. Jun JH, Yaksh TL. The effect of intrathecal gabapentin and 3-isobutyl gamma-aminobutyric acid on the hyperalgesia observed after thermal injury in the rat. Anesth Analg 1998;86:348-54.

14. Dallocchio C, Buffa C, Mazzarello P, Chiroli S. Gabapentin vs. amitriptyline in painful diabetic neuropathy: an open-label pilot study. J Pain Symptom Manage 2000;20:280-5.

15. Dworkin RH, O'Connor AB, Backonja M, Farrar JT, Finnerup NB, Jensen TS, et al. Pharmacologic management of neuropathic pain: evidence-based recommendations. Pain 2007;132:237-51.

16. O'Connor AB, Dworkin RH. Treatment of neuropathic pain: an overview of recent guidelines. Am J Med 2009;122(10 Suppl):S22-32.

17. Vadalouca A, Raptis E, Moka E, Zis P, Sykioti P, Siafaka I. Pharmacological treatment of neuropathic cancer pain: a comprehensive review of the current literature. Pain Pract 2012;12:219-51.

18. Drug treatment of neuropathic pain. Drug Ther Bull 2000;38:89-93.

19. Coluzzi F, Mattia C. Mechanism-based treatment in chronic neuropathic pain: the role of antidepressants. Curr Pharm Des 2005;11:2945-60.

20. Verdu B, Decosterd I, Buclin T, Stiefel F, Berney A. Antidepressants for the treatment of chronic pain. Drugs 2008;68:2611-32.

21. Ayoub SS, Colville-Nash PR, Willoughby DA, Botting RM. The involvement of a cyclooxygenase 1 gene-derived protein in the antinociceptive action of paracetamol in mice. Eur $\mathrm{J}$ Pharmacol 2006;538(1-3):57-65.

22. Ouellet M, Percival MD. Mechanism of acetaminophen inhibition of cyclooxygenase isoforms. Arch Biochem Biophys 2001;387:273-80.

23. Botting RM. Mechanism of action of acetaminophen: is there a cyclooxygenase 3? Clin Infect Dis 2000;31 Suppl 5:S202-10.

24. Aronoff DM, Oates JA, Boutaud O. New insights into the mechanism of action of acetaminophen: Its clinical pharmacologic characteristics reflect its inhibition of the two prostaglandin $\mathrm{H} 2$ synthases. Clin Pharmacol Ther 2006;79:9-19.

25. Bertolini A, Ferrari A, Ottani A, Guerzoni S, Tacchi R, Leone S. Paracetamol: new vistas of an old drug. CNS Drug Rev 2006;12(3-4):250-75.

26. Mallet C, Daulhac L, Bonnefont J, Ledent C, Etienne M, Chapuy E, Libert F, Eschalier A. Endocannabinoid and serotonergic systems are needed for acetaminophen-induced analgesia. Pain 2008;139:190-200.

27. Bujalska M, Gumułka WS. Effect of cyclooxygenase and NO synthase inhibitors on 
antinociceptive action of acetaminophen. Pol J Pharmacol 2001;53:341-50.

28. Curros-Criado MM, Herrero JF. Antinociceptive effects of NCX-701 (nitro-paracetamol) in neuropathic rats: enhancement of antinociception by co-administration with gabapentin. Br J Pharmacol 2009;158:601-9.

29. Matsunaga A, Kawamoto M, Shiraishi S, Yasuda T, Kajiyama S, Kurita S, Yuge O. Intrathecally administered COX-2 but not COX-1 or COX-3 inhibitors attenuate streptozotocin-induced mechanical hyperalgesia in rats. Eur J Pharmacol 2007;554:12-7.

30. Im KS, Jung HJ, Kim JB, Lee JM, Park HJ, Joo CH, Moon DE. The antinociceptive effect of acetaminophen in a rat model of neuropathic pain. Kaohsiung J Med Sci 2012;28:251-8.

31. Raffa RB, Clark-Vetri R, Tallarida RJ, Wertheimer AI. Combination strategies for pain management. Expert Opin Pharmacother 2003;4:1697-708.

32. Gatti A, Sabato AF, Carucci A, Bertini L, Mammucari M, Occhioni R. Adequacy assessment of oxycodone/paracetamol (acetaminophen) in multimodal chronic pain: a prospective observational study. Clin Drug Investig 2009;29 (Suppl 1):31-40.

33. Romanò CL, Romanò $\mathrm{D}$, Lacerenza $\mathrm{M}$. Antineuropathic and antinociceptive drugs combination in patients with chronic low back pain: a systematic review. Pain Res Treat 2012;2012:154781.

34. Hama AT, Sagen J. Cannabinoid receptor-mediated antinociception with acetaminophen drug combinations in rats with neuropathic spinal cord injury pain. Neuropharmacology 2010;58(4-5):75866.

35. Durmus M, Kadir But A, Saricicek V, Ilksen Toprak H, Ozcan Ersoy M. The post-operative analgesic effects of a combination of gabapentin and paracetamol in patients undergoing abdominal hysterectomy: a randomized clinical trial. Acta Anaesthesiol Scand 2007;51:299-304.

doi:10.5455/2319-2003.ijbcp20130611

Cite this article as: Bankar MA, Dudhgaonkar SS.

Anti-hyperalgesic effect of paracetamol in rat model of thermal hyperalgesia: implications for the treatment of neuropathic pain. Int J Basic Clin Pharmacol 2013;2:290-7. 